\title{
Mackenzie River Peregrine Falcon Surveys 1966-2018
}

\author{
Keith Hodson
}

Received: September 17, 2018 -Revised: December 09, 2018 -Accepted: January 09, 2019

This is a contribution submitted to the Proceedings of the World Conference on the Peregrine Falcon in Budapest in September 2017.

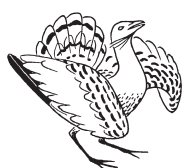

Hodson, K. 2018. Mackenzie River Peregrine Falcon Surveys 1966-2018. - Ornis Hungarica 2018(2): 134-142. DOI: 10.1515/orhu-2018-0022

Abstract The author with assistants monitored the breeding distribution of Peregrine Falcons (Falco peregrinus) along the length of the Mackenzie River, Northwest Territories, Canada from 1966 to 2018. This river traverses a thousand miles $(1600 \mathrm{~km})$ of the western Canadian Arctic from Great Slave Lake to the Beaufort Sea and roughly parallels the eastern slope of the Mackenzie Mountain cordillera between latitudes 61 degrees $\mathrm{N}$ and 68 degrees $\mathrm{N}$.

All potential nest sites have been checked on each survey and counts of nest sites occupied (at least one bird seen) decreased from the count of 12 sites in 1966 to the lowest count of 7 in 1972. In 1990 the count was 37 and up to 2018 the highest count was 75 in 2010.

A count of nest sites successfully producing young was variable with a low of 5 in 1972 to a high of 58 in 2011.

Production of young averaged 2.43/successful site from 1990 until 2018 (excluding 2012). Production of young averaged 1.4/ occupied site over this period. Recent increases in availability of passerine prey because of widespread fires in the last decades are felt to be the latest phenomena affecting these birds (pers.obs.) Prey utilized by Peregrines was studied over a period of four years and passerines composed $20 \%$ of their diet. Two species Lesser Scaup (Athya affinis) and Lesser Yellowlegs (Tringa flavipes) formed 25\% of their diet.

Keywords: Mackenzie River, Peregrine, 50 year surveys, population, pesticides, PIT monitoring, maggots, prey

Összefoglalás A szerző asszisztenseivel monitorozta a vándorsólyom (Falco peregrinus) elterjedését a Mackenzie folyó teljes hosszán, Kanada északnyugati területein 1966 és 2018 között. A folyó 1600 km-en keresztül átszeli Kanada arktikus területeinek nyugati részét a Nagy-Rabszolga-tótól a Beaufort-tengerig, és nagyjából párhuzamosan a Mackenzie hegylánc keleti lejtőivel az É $61^{\circ}$ és az É $68^{\circ}$ szélesség között. Minden felmérés alkalmával az összes potenciális fészkelőhelyet ellenőriztük. Az elfoglalt fészkelőhelyek száma (ahol legalább egy madarat láttunk) az 1966-ban számlált 12-röl az 1972-es évre a legalacsonyabb 7-re csökkent. 1990-ben 37 elfoglalt fészkelöhelyet számláltunk, és 2018-ra is a legmagasabb számlálási érték 75 volt 2010-ben. A sikeresen költő párok száma változó volt, az 1972-es legalacsonyabb 5-től a 2011-ben számlált legmagasabb 58-ig.

Az átlagos fiókaszám 2,43 volt sikeres fészkelésenként 1990 és 2018 között (kivéve 2012). Az átlagos fiókaszám 1,4 volt elfoglalt fészkelőhelyenként ugyanezen időszak alatt. Az énekesmadár zsákmányellátottság recens növekedése - ami az elmúlt évtizedek kiterjedt erdőtüzeinek köszönhető - a legutóbbi jelenség, ami befolyásolja a sólymokat (személyes megfigyelés). A vándorsólymok zsákmányállatait egy négy éves időszakon keresztül vizsgáltuk, amikor a zsákmány 20\%-a énekesmadár volt. Két faj, a búbos réce (Aythya affinis) és a sárgalábú cankó (Tringa flavipes) tette ki a táplálék 25\%-át.

Kulcsszavak: Mackenzie folyó, vándorsólyom, 50 év felmérés, állomány ingadozás, növényvédőszerek, PIT monitoring, nyü, zsákmány 


\section{Introduction}

"The Peregrine Falcon could be called the world's most successful flying bird, since it occurs in all continents and on many oceanic islands and is everywhere a bird of supreme skill, grace and precision in flight"(quote from Amadon \& Brown 1968). It is a highly dynamic aerial hunter feeding almost entirely on other avian species some as large as themselves. Some subspecies are known to feed extensively on bats and on large insects (locusts) and pairs known to be predominately bird feeders sometimes take small mammals. Accurate methods of recording have indicated they may reach in excess of an astonishing $444 \mathrm{~km}$ in a dive. Not all prey is taken in a dive though for coastal Peregrines (subspecies Peale's) are reported to sometimes hunt at sea level at high speed. They will spot their prey (murrelets) from afar then drop into a trough between the waves on their approach, whipping over the crest of the waves and into the flock of water skimming birds. Once the murrelet has been "decked" the falcon will engineer a retrieval from the water and return to land (Nelson 1977). Many species are taken by Peregrines including shorebirds, alcids, waterfowl, gulls and passerines.

Occasionally other raptors are also taken. In the 1950's and 1960's the Peregrine drastically declined throughout the world with the most noticeable areas of decline in Europe and North America where they had been studied extensively. Enderson et al. (1995) summarize the situation for North America: “Overall this species disappeared by the mid 1970's from temperate regions east of the plains and fell to below one-quarter of former numbers in the west where counts were rudimentary. The Pacific Northwest maritime population was little affected especially in the Aleutians. In interior Alaska and northern Canada, we estimate numbers fell to about a third or less of the pre-decline level.“

By the late 1960's sufficient research had been conducted to indict the chlorinated hydrocarbon pesticides as the cause, especially DDT, dieldrin and related compounds. Birds poisoned by these pesticides were eaten by Peregrines who would accumulate residue high enough to affect reproduction. Eggshells became thinner and would crack when being incubated (Ratcliffe 1958). Breeding behavior was also affected.

\section{Materials and Methods}

For all survey years from 1969 until the present, the length of the Mackenzie River was travelled by motorboat in July and early August and all known and potential nesting sites were searched intensively for occupancy, looking for telltale presence of "whitewash" (excrement) at perching sites, and for the presence of the birds. Where "whitewash" was abundant the sites were climbed whether the birds were seen or not, and in a few cases nest sites with young were found although the adults were never seen. Occasionally it took the firing of a 22 rifle to rouse the adults at an occupied site.

Over 100 different sites used by Peregrines have been recorded and all were checked each year. In some cases the sites are no longer suitable because of erosion, mass slumping, and the effects of river ice destroying the cliff face. Both sides of the river (up to $2 \mathrm{~km}$ apart) 
were surveyed; and sometimes one side of the river was covered going downriver and the opposite side of the river covered on the return trip. Where it was possible young Peregrines were banded and aged. On the 2000, 2005, 2010 and 2013 surveys the prey utilized by Peregrines was studied. All prey samples in the immediate vicinity of nesting sites were collected including avian primaries, tail feathers, wings, feet and heads and any items from the occasional small mammal. Prey and pellets were collected from 87 eyrie visits.

Feathers were keyed out using reference material collected on site and by the use of reference books (Godfrey 1986, Dunn \& Alderfer 2011) and reference keys that use nodes on the feather barbules to identify specimens to Order (Day 1966).

The linear survey along the river is not all inclusive of the Mackenzie River valley because there are sites away from the river that couldn't be checked. In order to include these sites in the five year surveys $(1990,1995,2000,2005,2010,2015)$ the ENR (Environment and Natural Resources) of the NWT government has been conducting a helicopter survey in conjunction with our river survey that includes at least 10 additional sites in the Mackenzie Valley.

\section{Results}

In 1966 a survey showed a population of 12 active sites and these numbers did not change quickly with the elimination of organochlorine pesticides in the early 1970's. However the shift in numbers had begun and by 1990 there were 37 occupied sites along the river with 26

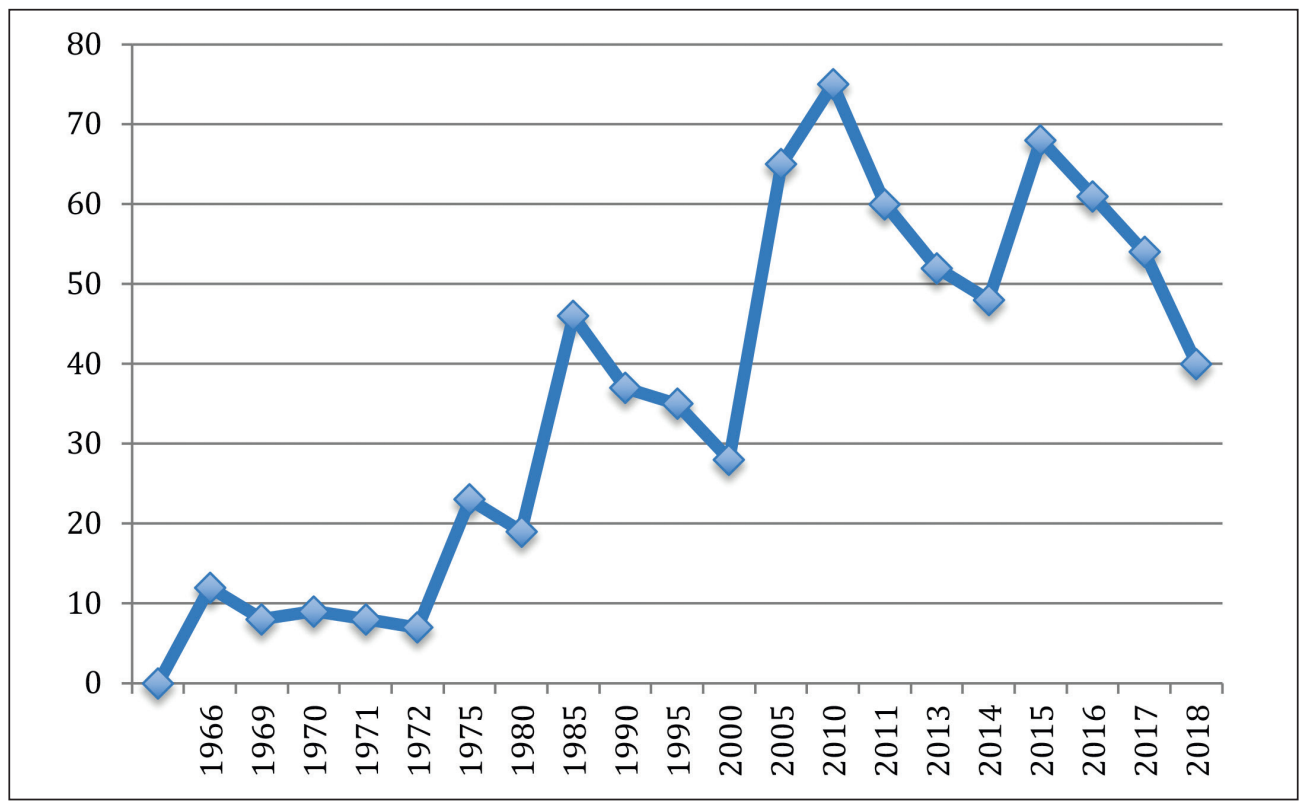

Figure 1. Changes in Peregrine Falcon site occupancy at the Mackenzie River, 1966-2018.

1. ábra A vándorsólyom foglalt fészkelőhelyeinek változása 1966-2018 között a Mackenzie-folyó mentén 
sites successfully raising young. By 2015numbers had doubled again with 68 occupied sites and 44 sites successfully raising young. The results of 17 surveys from 1966 to 2018 is presented in Figure 1 and in Table 1.

There were 399 identified prey from 55 species and 108 identified to grouping order (Table 2). In the 507 samples, shorebird (37\%) diving ducks (25\%) and the passerines $(21 \%)$ were the most common prey grouping contributing to about $80 \%$ of total prey of the identified prey, Lesser Scaup (13.8\%) contributed the largest number of individuals and Lesser Yellowlegs $(11.5 \%)$ the second highest contribution. Overall the Peregrines had a very broad diet eating a wide range of the avian species available along the Mackenzie River. Only birds too big for Peregrines to handle including large waterfowl, corvids, and raptors were absent from the diet. One noted prey included the Yellow Rail (Coturnicops noveboracensis) a wing from which was found in a Peregrine eyrie some $500 \mathrm{~km}$ north of its previously reported most northerly location. Since 2011, 367 young falcons have been fitted with PIT (Passive integrated Transponder) bands to study mortality, dispersal and turnover of breeding individuals (after Smith \& McGrady 2008). We assumed PIT banded individuals would start turning up in the breeding population by 2014-15 but in 2017 we detected a PIT banded bird in the breeding population for the first time (photo only, no data) 482 bands have been put on young Peregrine Falcons since 1969 by the author. From these birds there have been three returns, a bird found in Cuba 1 year 7 months after banding that had travelled $6,262 \mathrm{~km}$, a bird trapped and released in Texas $2 \frac{1}{2}$ months after banding that had travelled about $4500 \mathrm{~km}$ and a bird found in Chile 5 months after banding that had travelled $11,065 \mathrm{~km}$. These distances are exceeded by two others banded by the author about $150 \mathrm{~km}$ to the east of the Mackenzie River valley, a bird found in Colombia 3 months after banding

Table 1. Site productivity 1966-2018 (1975, 1980, 1985 ENR Helicopter)

1. táblázat Fészkelési adatok

\begin{tabular}{|l|c|c|c|c|c|c|c|c|c|c|c|c|c|c|c|c|c|c|c|c|}
\hline Year $^{1}$ & 66 & 69 & 70 & 71 & 72 & 75 & 80 & 85 & 90 & 95 & 00 & 05 & 10 & 11 & 13 & 14 & 15 & 16 & 17 & 18 \\
\hline Sites Occupied ${ }^{2}$ & 12 & 8 & 9 & 8 & 7 & 23 & 19 & 45 & 37 & 35 & 28 & 65 & 75 & 60 & 52 & 48 & 68 & 61 & 54 & 40 \\
\hline Sites Active & 12 & 8 & 3 & 5 & 7 & & & & 34 & 28 & 21 & 60 & 65 & 51 & 37 & 33 & 52 & 54 & 46 & 29 \\
\hline Sites Successful & & & & & 5 & & & & 26 & 26 & 13 & 44 & 48 & 38 & 18 & 28 & 44 & 42 & 18 & 18 \\
\hline Sites Failed & & & & & & & & & 6 & 2 & 7 & 11 & 16 & 3 & 15 & 2 & 3 & 7 & 14 & 12 \\
\hline $\begin{array}{l}\text { Success } \\
\text { Unknown }\end{array}$ & & & & & 2 & & & & 2 & & 1 & 5 & 1 & 10 & 4 & 3 & 5 & 5 & 14 & 10 \\
\hline $\begin{array}{l}\text { Sites Counted \& } \\
\text { Banded }\end{array}$ & & & & 5 & & & & 26 & 22 & 11 & 39 & 45 & 28 & 17 & 20 & 38 & 41 & 17 & 11 \\
\hline $\begin{array}{l}\text { Young Counted } \\
\text { \&anded }\end{array}$ & & & & 14 & & & & 67 & 51 & 28 & 94 & 115 & 65 & 32 & 51 & 97 & 113 & 40 & 24 \\
\hline $\begin{array}{l}\text { Young counted/ } \\
\text { Site }\end{array}$ & & & & & & & & 2.75 & 2.3 & 2.54 & 2.41 & 2.55 & 2.32 & 1.88 & 2.55 & 2.55 & 2.75 & 2.35 & 2.18 \\
\hline $\begin{array}{l}\text { Young Banded } \\
\text { Conventional }\end{array}$ & & & & & 10 & & & & 58 & 15 & 21 & 35 & 78 & 0 & 32 & 27 & 76 & 93 & 37 & 19 \\
\hline $\begin{array}{l}\text { Young Banded } \\
\text { PIT }\end{array}$ & & & & & & & & & & & & 75 & 33 & 32 & 25 & 77 & 93 & 26 & 19 \\
\hline $\begin{array}{l}\text { Sites young not } \\
\text { counted }\end{array}$ & & & & & & & 1 & 12 & 3 & 29 & 13 & 21 & 1 & 18 & 13 & 7 & 3 \\
\hline
\end{tabular}


Table 2. Peregrine Falcon diet on the Mackenzie River Northwest Territories ( $1 \%$ Diet is for identified prey only)

2. táblázat Vándorsólyom tápláléklista a Mackenzie folyó mentén

\begin{tabular}{|c|c|c|c|c|}
\hline Species Group & $\%$ of Diet & Species & Number & $\%$ Diet $^{1}$ \\
\hline \multirow{2}{*}{ Coots \& Rails } & & American Coot Fulicia americana & 4 & 1.0 \\
\hline & & Yellow Rail Coturnicops noveboracenis & 1 & 0.3 \\
\hline \multirow{6}{*}{ Dabbling Duck } & \multirow{6}{*}{8.9} & Mallard Anas platyrhynchos & 8 & 2.0 \\
\hline & & Green-winged Teal Anas crecca & 16 & 4 \\
\hline & & Blue-winged Teal Anas discors & 12 & 3 \\
\hline & & Northern Shoveler Anas clypeata & 6 & 1.5 \\
\hline & & American Widgeon Anas americana & 2 & 0.5 \\
\hline & & Northern Pintail Anas acuta & 1 & 0.3 \\
\hline \multirow{11}{*}{ Diving Duck } & \multirow{11}{*}{25} & Lesser Scaup Aythya affinis & 55 & 13.8 \\
\hline & & Greater Scaup Aythya marila & 10 & 2.5 \\
\hline & & Surf Scoter Melanitta perspicillata & 7 & 1.8 \\
\hline & & Bufflehead Bucephala albeola & 7 & 1.8 \\
\hline & & Canvasback Aythya valisineria & 6 & 1.5 \\
\hline & & Red-breasted Merganser Mergus serrator & 1 & 0.3 \\
\hline & & Common Merganser Mergus merganser & 4 & 1.0 \\
\hline & & Ring-necked Duck Aythya collaris & 3 & 0.8 \\
\hline & & Merganser spp. (unidentified) & 1 & 0.3 \\
\hline & & Harlequin Duck Histrionicus histrionicus & 1 & 0.3 \\
\hline & & Duck spp. (unidentified) & 32 & \\
\hline \multirow{2}{*}{ Grouse \& Ptramigan } & \multirow{2}{*}{0.6} & Ruffed Grouse Bonasa umbellus & 2 & 0.5 \\
\hline & & Rock Ptarmigan Lagopus mutus & 2 & 0.5 \\
\hline \multirow{4}{*}{ Gull } & \multirow{4}{*}{6.9} & Mew Gull Larus canus & 23 & 5.8 \\
\hline & & Bonaparte's Gull Larus philadelphia & 1 & 0.3 \\
\hline & & Long-tailed Jaeger Stercuraius longicaudus & 1 & 0.3 \\
\hline & & Gull spp. (unidentified) & 1 & \\
\hline \multirow{2}{*}{ Loons \& Grebes } & \multirow{2}{*}{2.8} & Horned Grebe Podiceps auritus & 9 & 2.3 \\
\hline & & Red-necked Grebe Podiceps grisgena & 5 & 1.3 \\
\hline
\end{tabular}




\begin{tabular}{|c|c|c|c|c|}
\hline Species Group & $\%$ of Diet & Species & Number & $\%$ Diet $^{1}$ \\
\hline \multirow{17}{*}{ Passerines } & \multirow{17}{*}{20.7} & Say's Phoebe Sayornis saya & 8 & 2.0 \\
\hline & & Gray Jay Perisoreus canadensis & 11 & 2.8 \\
\hline & & American Robin Turdus migratorius & 5 & 1.3 \\
\hline & & Bohemian Waxwing Bombycilla garrulus & 9 & 2.3 \\
\hline & & Bank Swallow Riparia riparia & 1 & 0.3 \\
\hline & & $\begin{array}{l}\text { Yellow-rumped Warbler Dendroica } \\
\text { coronata }\end{array}$ & 4 & 1.0 \\
\hline & & Northern Shrike Lanius excubitor & 1 & 0.3 \\
\hline & & Swainson's Thrush Catharus ustulatus & 3 & 0.8 \\
\hline & & Water Pipit Anthus spinoletta & 1 & 0.3 \\
\hline & & Townsend's Solitaire Myadestes townsendi & 1 & 0.3 \\
\hline & & Fox Sparrow Passerella iliaca & 1 & 0.3 \\
\hline & & Rusty Blackbird Euphagus carolinus & 1 & 0.3 \\
\hline & & Grey-cheeked Thrush Catharus minimus & 1 & 0.3 \\
\hline & & Blackbird spp. (unidentified) & 3 & 0.8 \\
\hline & & Small Passerine (unidentified) & 24 & \\
\hline & & Northern Flicker Colaptes auratus & 23 & 5.8 \\
\hline & & $\begin{array}{l}\text { Three-toed Woodpecker Picoides } \\
\text { tridactylus }\end{array}$ & 1 & 0.3 \\
\hline \multirow{3}{*}{ Raptor } & \multirow{3}{*}{1.4} & American Kestrel Falco sparverius & 3 & 0.8 \\
\hline & & Short-eared Owl Asio flammeus & 2 & 0.5 \\
\hline & & Sharp-shinned Hawk Accipiter striatus & 2 & 0.5 \\
\hline \multirow{10}{*}{ Shorebird } & \multirow{10}{*}{32.7} & Upland Sandpiper Bartramia longicauda & 16 & 4.0 \\
\hline & & Lesser Yellowlegs Tringa flavipes & 46 & 11.5 \\
\hline & & Spotted Sandpiper Actitis macularia & 17 & 4.3 \\
\hline & & Solitary Sandpiper Tringa solitaria & 12 & 3.0 \\
\hline & & Common Snipe Gallinago gallinago & 9 & 2.3 \\
\hline & & Least Sandpiper Calidris minutilla & 4 & 1.0 \\
\hline & & Golden Plover Pluvialis dominica & 7 & 1.8 \\
\hline & & Black-bellied Plover Pluvialis squatarola & 1 & 0.3 \\
\hline & & $\begin{array}{l}\text { Short-billed Dowitcher Limnodromus } \\
\text { scolopaceus }\end{array}$ & 16 & 4 \\
\hline & & Shorebirds spp. (unidentified) & 38 & \\
\hline \multirow[t]{3}{*}{ Small Mammal } & & Small Mammal & 1 & \\
\hline & & All Prey & 507 & \\
\hline & & Identified Prey & 399 & \\
\hline
\end{tabular}


Table 3. Peregrine Falcon band returns (from Dunn et al. 2009)

3. táblázat Vándorsólyom megkerülési adatok (Dunn et al. 2009 alapján)

\begin{tabular}{|c|c|c|c|c|c|}
\hline Band Date & Band & $\begin{array}{c}\text { Banding } \\
\text { location }\end{array}$ & Recovery Date & $\begin{array}{c}\text { Recovery } \\
\text { Location }\end{array}$ & Km travelled \\
\hline $17 / 07 / 69$ & $727-00003$ & $\begin{array}{c}\text { Fort Good Hope } \\
66^{\circ} \mathrm{N} 129^{\circ} \mathrm{W}\end{array}$ & $14 / 03 / 71$ & $\begin{array}{c}\text { Cuba } \\
20^{\circ} 40^{\prime} \mathrm{N} \\
77^{\circ} 00^{\prime} \mathrm{W}\end{array}$ & 6,262 \\
\hline $16 / 07 / 73$ & $727-00307$ & $\begin{array}{c}\text { Arctic Red River } \\
6^{\circ} \mathrm{N} 133^{\circ} \mathrm{W}\end{array}$ & $04 / 12 / 73$ & $\begin{array}{c}\text { Chile } \\
20^{\circ} 10^{\prime} \mathrm{S} \\
70^{\circ} 00^{\prime} \mathrm{W}\end{array}$ & 11,065 \\
\hline $01 / 07 / 72$ & $617-21375$ & $\begin{array}{c}\text { Anderson River } \\
69^{\circ} \mathrm{N} 128^{\circ} \mathrm{W}\end{array}$ & $03 / 11 / 72$ & $\begin{array}{c}\text { Colombia } \\
02^{\circ} 10^{\prime} \mathrm{N} \\
78^{\circ} 30^{\prime} \mathrm{W}\end{array}$ & 8,351 \\
\hline $30 / 07 / 73$ & $686-01703$ & $\begin{array}{c}\text { Horton River } \\
69^{\circ} \mathrm{N} 126^{\circ} \mathrm{W}\end{array}$ & $01 / 10 / 74$ & $\begin{array}{c}\text { Argentina } \\
29^{\circ} 00^{\prime} \mathrm{S} \\
66^{\circ} 50^{\prime} \mathrm{W}\end{array}$ & 11,969 \\
\hline $11 / 07 / 16$ & $1687-11804$ & $\begin{array}{c}\text { Fort Good Hope } \\
66^{\circ} \mathrm{W} 128^{\circ} \mathrm{W}\end{array}$ & $09 / 30 / 16$ & $\begin{array}{c}\text { Padre Island } \\
26^{\circ} 28^{\prime} \mathrm{S} \\
97^{\circ} 38^{\prime} \mathrm{W}\end{array}$ & 4,500 \\
\hline
\end{tabular}

that had travelled 8,351 km and a bird found 1 year 3 months after banding in Argentina that had travelled 11,969 km (Table 3).

\section{Discussion}

The graph (Figure 1) showing the declining counts of occupied sites until the early 1970's and then the subsequent resurgence until recently shows a remarkable similarity to a number of studies of Eurasian Peregrines over the same period (Sielicki \& Mizera 2007). This further substantiates it was the catastrophic effects of organochlorine pesticides in the 1950's and 60's that was pushing numerous top of the food chain species like Peregrines toward extermination. Our figures indicate that the Mackenzie River Peregrine numbers were severely depleted when they were first counted in 1966, about $20 \%$ of the high count in 2016 (or decline of $80 \%$ by 1966) if we assume carrying capability of the river system had not changed.

A period of rain and severe summer storms when the precipitation is driven into nesting ledges is a factor affecting survival of nestling Peregrines. In 2013 a storm went through the area about Fort Good Hope the third week of June and at 10 nesting sites notes were made that the sites were terribly eroded, slumped or inundated by mud, a result of exceptional periods of rain during the early nesting period. Nestling falcons were buried in mudslides at two sites and two eyasses were found dead below their eyrie after the storm. A more generalized storm period occurred in 2017 and the young at three eyries were found dead in mid-July and nesting ledges were covered by mud at two other sites. 2018 was the poorest year in terms of occupied sites, successful sites and productivity since 2000. This is attributed to a combination of adverse weather again resulting in destroyed sites and one brood killed, and maggot infestation in three eyries. In one of these three the only remaining young was 
dying and in the second one young was not going to survive. However, in the third all three young had swollen, open ears but the maggots appeared to have had hatched and flown. In 2005 at a few nests young birds were first noted to have maggots coming out of their ears) and in subsequent surveys this seemed to be an increasing problem. It appears that a fly is laying eggs in their ears (because temperatures are rising earlier in the spring than previously and the flies are hatching earlier?). In 2016, 41 nest sites were banded and young checked for maggots; 7 had maggots or $17 \%$ of the nests. All young at infected sites were infected. It may not be as bad as it appears though for at sites where I did not think the young would survive because of infestation on a second check of the site to band young about 2 weeks later, the maggots had hatched and flown and the tissue about the falcon's ears was scabbed over and seemed to be healing. On one young similar maggots also were found under the feathers still in blood and causing a terrible mess of the growing feathers Maybe a little squirt of DDT is needed to kill flies and maggots! A veterinarian acquaintance who has worked in the arctic called this maggot problem a condition called myiasis that he has treated in dogs and seen in caribou and wood buffalo caused by the eggs laid by bot flies.

Climate change is having a direct effect on Peregrine nesting along the Mackenzie River. Many nesting sites are on "mud" cliffs sometimes as much as $100 \mathrm{~m}$ high presumably held there by frozen permafrost. As the permafrost melts back the cliffs slumps. In a number of cases the falcons have kept on nesting even though their nest site has moved away from its original location.

Despite natural adversity such as occurred during periods of inclement weather or direct mortality by parasites (i.e. the fly maggot) the Mackenzie River Peregrines have increased about threefold since first counted in 1966. The average productivity since 2000 for occupied sites ("active" sites in table 1) is 1.4 , which is the average for northern Peregrines (Franke 2016). It would appear that productivity is adequate in this western Canadian population of Peregrine Falcons. Future monitoring will determine if the decreased productivity the past two years is of concern and can be attributed to factors not yet determined.

\section{Acknowledgement}

There have been seventeen trips on the Mackenzie River from 1966 until 2018 to Monitor Peregrine Falcon nesting numbers. My wife and myself did all trips including two trips by ourselves. Each other trip had one or two volunteers along. They were Randy Semeniuk, Edmonton, Alberta 1969, Kim Hodson, Victoria B. C. 1970, Glen and Thea Ewald, Smithers, B. C. 1990, Bob Little, Smithers, B. C. 1995, John Franken, Smithers, B. C. 2000, Wayne and Betty Sager, Abbotsford, B. C. with John Campbell, Calgary, Alberta 2005, Frank and Kathy Doyle, Smithers B. C. with Jeff Amos, Hazelton B. C. 2010, Craig Hodson, Victoria B. C. 2012, Bob and Evelyn Veitch, Telkwa, B. C. 2013, Arnie Dyson Telkwa, B. C. 2015, Frank Guillon, Smithers B. C. 2016 and Myron Smaha, Wayne Collison and Tom Smith Smithers B. C. 2017.

Many other people assisted especially in obtaining supplies and fuel. Of special note include Doug Whiteman, Norman Wells, Richard Popko, Wildlife Technician in Norman 
Wells, Mabel, Renewable Resources Fort Good Hope and staff at Imperial Oil in Norman Wells and Arctic Petroleum in Inuvik.

Special thanks are due to Frank Doyle of Wildlife Dynamics Consultants Smithers B. C. who spent many hours with me sorting and identifying prey samples.

\section{References}

Amadon, D. \& Brown, L. 1968. Eagles, Hawks and Falcons of the World. - Hamlyn Publishing Group Ltd. Hamlyn House, 18 Feltham, Middlesex, Great Britain

Bromley, R. G. \& Mathews, S. B. 1988. Status of the Peregrine Falcon in the Mackenzie River Valley, Northwest Territories 1969-1985. - In: Cade, T. J. \& Endersson, J. H. (eds.) Populations: their Management and Recovery. - The Peregrine Fund Inc. Boise, Idaho, pp. 59-64.

Day, M. G. 1966. Identification of hair teeth remains in the gut and faeces of stoats and weasels. - Journal of Zoology 148: 201-217. DOI: 10.1111/j.1469-7998.1966.tb02948.x

Dunn, J. L. \& Alderfer, J. 2011. Field Guide to the Birds of North America. $6^{\text {th }}$ edition. - National Geographic, Washington D.C.

Dunn, E. H., Brewer, A. D., Diamond, A. W., Woodsworth, E. J. \& Collins, B. T. 2009. Canadian Atlas of Bird Banding, Vol. 3, Raptors and Waterbirds, 1921-1995. - Special Publication, Canadian Wildlife Service, Ottawa, Ontario, Canada K1A 0H3

Enderson, J. H., Heinrich, W., Kiff, L. \& White, C. M. 1995. Population changes in North American Peregrines. - Transactions of the North American Wildlife and Natural Resources Conference 60: 142-161.

Franke, A. 2016. Population estimates for northern juvenile Peregrine Falcons with harvest levels in North America. - Journal of Fish and Wildlife Management 7(1): 36-45. DOI: 10.3996/062015-JFWM-050

Godfrey, W. E. 1986. The Birds of Canada. Revised edition. - National Museum of Canada

Ratcliffe, D. A. 1958. Broken eggs in Peregrine eyries. - British Birds 51(1): 23-26.

Sielicki, J. \& Mizera, T. (eds.) 2007. Proceedings of the $2^{\text {nd }}$ International Peregrine Conference 19-23 September 2007, Piotrowo, Poland

Smith, G. D. \& McGrady, M. J. 2008. Using passive integrated transponder (PIT) tags to better understand Peregrine Falcon population in South Scotland and North East England. - In: Sielicki, J. \& Mizera, T. (eds.) Peregrine Falcon populations - status and perspectives in the $21^{\text {st }}$ century. - Turul Publishing and Poznan University of Life Sciences Press, Warsaw, Poland, pp. 245-258.

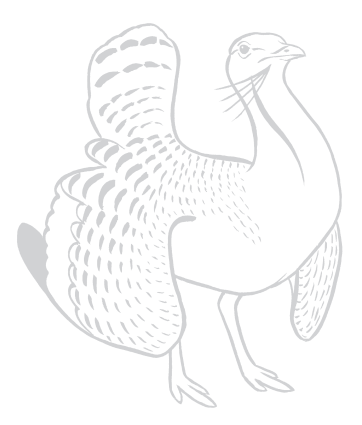

